UDC 378.147:004

Iryna L. Pokrovska

Doctor of Philology, Associate Professor, Head of the Department of Turkish Studies

Taras Shevchenko National University of Kyiv, Kyiv, Ukraine

ORCID ID 0000-0002-7826-3148

irem2003@ukr.net

\title{
FORMATION OF MEDIA COMPETENCE OF STUDENTS OF HUMANITARIAN FACULTIES DURING THE STUDY OF SPECIALIZED DISCIPLINES
}

\begin{abstract}
The article represents the results of an experimental study on the formation of the media competence of the student's personality in the context of media education. The definitions of key terms have been given: media education, media literacy, media competence. Based on the experience of the higher educational establishments of Germany, the experimental study made it possible to trace both common and distinguishing characteristics in the formation of media competence. At the establishing stage of the experiment the following tasks were addressed: the pedagogical essence of the development of media competence of university students in Ukraine and the FRG; the elaboration of the criteria, levels and stages of development of the students' media competence; the identification of the initial level of the media competence development of Ukrainian university students. At the forming stage, the research was concerned with highlighting of the media strengths of Ukrainian and German students in a comparative analysis, as well as checking the efficiency of the pedagogical conditions for the development of media competence of the university students. The results of the establishing stage of the experimental work revealed an insufficient level of development of media competence of Ukrainian university students, pointed out their main media preferences as value orientations in media space. The result of the forming stage is the development and implementation of the model of media competence development in the university educational process, making use of the German pedagogical experience of personality mediatization. In the course of the German language practical classes and in the optional course the following media education methods were used: the mediaobiographic method, the method of narrative analysis of media text, L. Kolberg's method of moral dilemma. Thus, the experimental and peda gogical work carried out allows us to conclude that the implemented pedagogical methods promote the development of the levels of students' media competence, as evidenced by the positive dynamics of the studied indicators among the Ukrainian students.
\end{abstract}

Keywords: media education; media literacy; media competence; research experimental study; establishing and forming stages.

\section{INTRODUCTION}

Problem Statement. A key feature of the development of modern society is the informatization of all spheres of its life. One of the conditions of informatization of a society is the informatization of education, the process of which, as a rule, affects all directions of educational activity, sets new goals and objectives, changes the requirements for the competence of pupils, students, etc. As a result, the changing paradigm of education focuses on personalityoriented learning, independent and individual work of pupils, students, etc., taking into account the current level of informatization and global telecommunications. This leads to a new understanding of the readiness of graduates of educational institutions for life and professional activity in the modern information society.

Thus, the problem of the formation and development of media competence is emphasized at present, particularly the focus is on the media competence of the student's personality (works 
of R. Kubey, J. Potter et al.) as a key figure in media education. Being conditioned by the general tendency of computerization and informatization of the society, it causes radical transformations in the open educational space. That is why one of the key tasks of the teacher is the development of the media competence of the student's personality, which is necessary for the professional culture of future specialists of all fields. Besides, the formation of media competence is one of the topical issues of language training methods.

Literature Review. In modern science, the preconditions are created and a certain fund of knowledge has been accumulated for the analysis and solving of the problem of development of the media competence of the student's personality.

M. McLuhan was one of the first scholars who studied the effects of communication technologies on the organization of cognitive processes in society. W. Martin, his colleague, outlined and formulated the main characteristics of the information society. The content of the notion and typology of "media" were considered by $\mathrm{H}$. Bonfadelli, H. Pross. The questions of the influence of the media environment on a person were represented in the works of D. Baake, M. Castells, V. P. Kolomiets, L. Mikos, V. Sander, R. Hoffman, R. Folbrecht, T. Bakka, V. Ivanov, L. Karpets, Yu. Kazakov, O. Mokrohuz; O. Voloshenyuk, I. Zadorozhnaya, etc.

Due to the widespread use, the notions of media technologies, media competence, media literacy, media culture and media education are becoming topical objects of both foreign scholars $[1 ; 8 ; 16 ; 19 ; 22 ; 28$; , etc. $]$ and Ukrainian researchers $[2 ; 10 ; 11 ; 14 ; 21 ; 25 ; 31 ; 32$, etc. $]$. We draw attention to the fact that the contributions of scholars working in this direction make it possible to address the problem of media competence at the higher educational establishments $[18 ; 23 ; 25]$, as well as the secondary schools $[2 ; 21 ; 25 ; 31$, etc], within which one can speak of such theoretical postulates as: the conceptual provisions of the competence approach $[8 ; 29]$, the theory of media education $[10 ; 19 ; 30]$; the research in professional and mass media education $[14 ; 17]$; the interdisciplinary axiological theories $[13 ; 15]$; the works devoted to the study of media education in the anthropological context [18]; the works devoted to the study of problems of modern university education $[21 ; 23 ; 25]$.

Ukrainian researchers identify the main directions of media education [25] and outline the significance of the media space's influence on the consciousness and civic position of the Ukrainians $[2 ; 13]$. T. Bakka notes that the need to master the skills of the search, transmission, processing and analysis of information by special methods and technologies dictates new demands both for the teacher and the student in the context of media education [2]. Building on these findings, the National Conception for the Implementation of Media Education in Ukraine [3] came into force in Ukraine in 2010, which aims to "facilitate the development of an effective media education system in Ukraine in order to ensure the comprehensive training of children and young people for safe and effective interaction with the modern media, to form media information literacy and media culture according to their age, individual and other peculiarities" [3]. In 2016, the National Academy of Pedagogical Sciences of Ukraine approved a new version of the Conception [4]. The main objective of the Conception is to promote the development of an effective media education system in Ukraine, which should become the foundation of the state humanitarian security, the development and consolidation of civic society, countering external information aggression [4]. In 2018-2019, according to the educational reform of the New Ukrainian School, one of the key competences of the learners is information and media literacy [5]. Up to now, Media Literacy was only an optional or extracurricular subject at schools and universities.

In Ukraine, in the context of the rapid development of informatization of modern society, the development of media programs is an urgent problem that is being addressed today. For that 
purpose, the Educational program "Media education (media literacy)" was developed and approved for use nationwide [9]. Furthermore, understanding the problems of today's educational society, the Ministry of Education and Science of Ukraine recently approved a number of measures to increase the competence of pedagogical staff in order to raise awareness among the students. These important normative documents provide the incentive for the courses on media education in secondary schools as well as in higher pedagogical educational institutions.

In light of the above, the purpose of the article is to study the formation of the media competence of Ukrainian university students based on the experience of the higher educational establishments of Germany, tracing the common and the distinguishing characteristics in the formation hereof.

\section{METHODOLOGY OF RESEARCH}

In accordance with the set purpose, the basis of the formulation of theoretical provisions of the present study is substantiated by the following methods and procedures of research: the analysis of philosophical, psychological, pedagogical, methodological literature, as well as the study of the authentic media sources. The methods of empirical research included a synthesis of foreign experience; comparative analysis; observation; media biographic method; method of narrative analysis of media text; search activity; statistical processing of research materials using GrafStat software, Excel.

\section{RESULTS OF THE RESEARCH}

Up to date, among the scholars there is no unanimous agreement on the definition of the concept media. Initially, this term was used to refer to different means of communication (M. McLuhan). Subsequently, media were seen as a need for interpreting symbolic systems that differ in decoding ways. Along with the typology of the technical means of media, it is possible to trace not only the use of the notion media (H. Pross, H. Bonfadelli), but also of the concept multimedia ("multiple means of data transmission"). The latter was introduced by M. McLuhan, who was the first to reveal the regularity that the type of society is largely determined by the dominant type of communication in it, and human perception is the speed of the transmission of this information [19]. Attention should be drawn to the need to combine several areas (synergy) between mass media, media education and information technology [31].

In the middle of the 19th century, the creation of a global information hyperspace took place, which essentially transformed the modern reality. It happened because the most developed countries of the world community entered a qualitatively different stage of development, i.e. an information society. Its distinctive feature is the transformation of information into a global resource of mankind. There was an opportunity of electronic submission of information that increased the number of broadcasting means (text, graphics, animation, video, sound, etc.). All this gave an impetus not only to the formation of the media environment (media space) of a particular society, but also laid the fundamentals for the formation of a new educational space, which was designated as media education. The first generally recognized definition is the one pinpointed in the UNESCO documents in 1973. UNESCO's resolutions and recommendations have repeatedly emphasized the importance and necessity of media education. In particular, the recommendations of 2002 state that "media education is part of the fundamental right of every 
citizen of any country to freedom of self-determination and information, it promotes democracy. Acknowledging the difference in the levels of media education in the world, it is recommended to initiate and develop it whenever possible within national curricula, as well as in additional and non-formal education, in lifelong learning [20].

Within the framework of the umbrella term media education, an independent field of knowledge, the more specific concepts such as media literacy, media competence, media culture, etc. have been substantiated. For example, C. Shelby and F. Rogov define the purpose of education on media literacy as "to help individuals, regardless of age, develop skills to explore and be able to express what they need, so that they can critically think, communicate effectively and be effective active citizens in the modern world" [28, p. 18]. However, R. Kubey uses the terms "media competence" and "media literacy" as synonyms and interprets them as "the ability to use, analyze, evaluate and transmit messages in various forms" [16, p. 2].

We believe that the above-mentioned concepts are close in meaning to each other, i.e. they are compatible to each other, since they determine the development and competence of the individual in the field of media education and are considered as the goal of media education. At the same time, they are not absolutely identical, because they originally have different definitions, therefore, they are conceptual or ideographic synonyms. Many organizations in the EU member states have started projects to improve media literacy among their citizens, an example is the European Charter on Media Literacy. The objectives of the Charter are: promoting greater awareness of media literacy and media in education in Europe; raising the public significance of media literacy and media education in every European nation and in Europe as a whole; stimulating the development of a permanent and voluntary media network for teachers in Europe [7]. In documents of the European Parliament, media competence is understood as a "critical and thoughtful attitude towards the media in order to educate responsible citizens who can express their own judgments based on the information they receive, to enable them to use the necessary information, analyze it, identify economic, political, social and/or cultural interests, to interpret, create and choose messages that are the most suitable for media communication, as well as to allow people to exercise their right to freedom of expression [6]. In other words, such competence consists in the ability of critical thinking, adequate perception of information, the formation of personal judgment and position, the protection of individuals from manipulation by the media.

In addition, it should be emphasized that media competence in European scientific discourse has long been not only a media education notion, but also a social construct, i.e. an evaluation system with certain functions in the media community that is broadcast through the media. In various scientific discourses, the notion of media competence has different definitions. For example, in the field of economics, media competence is defined as a production factor, in the field of media law - as a regulatory factor in the context of protecting children's rights and consumer rights, in the field of politics - as an indicator of democratic competence. Broadly speaking, media competence is defined as the orientation of an individual or a social system towards self-organization based on the individual's ability to efficiently implement technical media in the field of communication, to understand the impact of the media and to hinder this impact in order to improve the quality of life in the information society (H. Gapski [8]). But in pedagogy, media competence is seen as a component of communicative competence and is defined as the ability to deliberately choose and use media technology, to create and distribute media texts, to understand media design, to discern and analyze media influence, to see and evaluate the conditions of production and distribution of media (D. Baake [1], G. Tulodziecki [30], etc.). 
The above-mentioned definitions reveal not only the individual skills, but also the reflection on their media-related activities, on media format and media criticism, and hereby the reflection on the ethical as well as socialized aspect.

Proceeding from the represented heterogeneity of the scientific field, the following working definition can be proposed: media competence is the result of the personalistic achievements of students in the process of formal and informal learning, which characterizes the readiness of a person to access the media.

In the process of investigation, a pilot and experimental study was conducted. Thus, by comparing the indicators of the most popular media concepts in Ukraine and the Federal Republic of Germany (hereinafter referred to as the FRG), it was found out that the highest valuemeaning content has a measure of media criticism, differentiated at the following levels: analytical, reflexive, ethical. The multidisciplinary practical application of such a notion in various educational institutions of the FRG [1;30], as well as the development of various teaching materials for it [26], gave an opportunity to use it in constructing a model for the development of media competence of Ukrainian university students.

In the national context media competence is determined as a result of education of future professionals $[4 ; 14]$. The research represents an analysis of the requirements for mastering of the fundamental educational programs for the bachelor's degree in the fields of philology, psychology, pedagogics, applied informatics, technology of products and catering. Proceeding from the objectives of our study, we have focused not only on the technical aspect of media use by students, but also on those competences that contribute to the development of media-criticism (the ability to formulate reasoned conclusions, the possession of a culture of thinking, the ability to perceive, analyze, generalize information, etc.). The theoretical analysis allowed us to develop the logic of the research, as well as to determine the pedagogical conditions for the development of media competence of Ukrainian university students: the definition of media space, within which the media competence as the living and educational space of students of higher educational establishments is determined; the actualization of the personal standpoint of the Ukrainian students in the course of implementing media projects; the use of the FRG's pedagogical experience of a personality's mediatization in the educational process of the Ukrainian university.

As a value-semantic matrix of the development of media competence of the university students, the coherence of the mechanisms was used: "search - assessment - choice projection", which ensures the ascent of personality to values (A. Kiriakova [15]). These mechanisms serve as a regulatory and informative benchmark for teachers in shaping the valuesemantic attitude of students to media space.

Let us formulate the main results of our experimental study comprising 2 main stages: the establishing one and the forming one, conducted with the involvement of students of higher educational establishments of Ukraine and the FRG.

At the establishing stage the following tasks were identified: to disclose the pedagogical essence of the development of media competency of students of higher education in Ukraine and the FRG; to develop the criteria, levels and stages of development of students' media competence; to identify the initial level of development of media competence of Ukrainian university students; to determine the media strengths of Ukrainian and German students in comparative analysis. Thus, according to the results of theoretical and practical analysis, the levels of development of media competence of university students were revealed and characterized according to criterion indicators reflecting the peculiarities of work on media projects.

Within the establishing stage of the study, a diagnosis of the formation of the students' 
media competency was conducted, in which 541 students of the National Pedagogical Drahomanov University (hereinafter referred to as the NPU) took part.

The factor analysis which utilized the software application GrafStat found out that $43.1 \%$ of students possessed the indifferent level, $54.9 \%$ - the potential and technological level, $1.5 \%$ the creative and technological level, $0.5 \%$ - the value and semantic level.

In addition, monitoring the preparation of students for annual scientific and practical conferences allowed to record the lack of readiness of NPU students to find the necessary information, to systematize and show its scientific significance.

Moreover, in the process of the study, a comprehensive diagnosis of "Media Strengths of Students" was conducted. 200 students from the Ludwigsburg Pedagogical Institute and 250 students from the NPU took part. This diagnosis (in comparative aspect) made it possible to identify media preferences as value orientations in the media space of Ukrainian and German students. As a result of the comparison, common media preferences for students of Ukraine and the FRG were revealed. When answering questions about the most used media in their free time, Ukrainian and German students put the Internet on the first place (49.5\% of Ukrainian students, $51 \%$ of German students). In the analysis of diagnostic data, the differences between Ukrainian and German students were noted in the motives of media consumption, as well as in the prevalence of media topics. Noting the main reasons for media contacts, Ukrainian students put the "desire to get new information" (67\%) on the first place, and German students preferred the "desire for entertainment" (84\%).

The Ukrainian students placed the youth, love and history topics $(49 \%, 45 \%, 41 \%$ respectively) on the first, second, and third place of the desired topics, highlighted in the media; the German students favoured the love (53\%), historical (44.5\%) and action (43\%) topics.

The results of this stage of the experimental study revealed an insufficient level of development of media competence of Ukrainian university students, highlighting their main media preferences as value orientations in media space.

At the forming stage of the research, the efficiency of pedagogical conditions for the development of media competence of university students was checked. At the outset, the Faculty of Journalism and the Faculty of Economics and Management of the NPU acted as the base for the forming stage of the study. Overall, 247 students took part at this stage.

The first pedagogical condition was the creation of the educational space for the institution of higher learning, which contributes to the value-based comprehension of the modern media environment by the students. The medium of the implementation of such a pedagogical condition was mediacriticism as a basic indicator of the development of media competence of university students.

Based on the educational standard on the subject "Foreign Language" at the German language practical classes, an additional educational effect was obtained that relates to the results of the study - improving media competence.

The following projects served to achieve this goal:

- the electronic educational resource "We study German" developed by the author, which has a value-oriented content and allowed students to comprehend the importance of developed media competence in professional activities; it showed the necessity for students to discuss topics that have socially significant fundamentals, i.e. they can identify themselves with the world around them;

- an optional course "Media Projects of University Students in Research Activity", which provided pedagogical support that allowed students to describe their own media 
biography, to obtain the necessary knowledge about the media, to develop the ability to analyze media texts with the presence of moral dilemma, which contributed to efficient work on media projects;

- a software application for the creation and processing of GrafStat surveys in German, combining the functions of constructing a survey, data collection, statistical processing of data and their graphical representation; it stimulated students to independent research activities.

Within the framework of the forming stage of the experiment, a series of problem-oriented seminars was conducted to the students of the Faculties of Journalism and Economics with the German teacher on the topic of the Ukrainian Presidential election as highlighted in both national and German mass media. The students were given the following tasks: to systematize the information on the topic from the Ukrainian and German mass media; to compare the information provided; to formulate the reasoned opinion on the specified problem. The normative beliefs, represented both in the Ukrainian and German mass media, served as a model for students to express their own point of view. The keynote feature in organizing this seminar is the participation of a highly skilled German teacher representing his own norms and evaluations while commenting on this or that media text and explaining German realities. The gaps were in the ability of students to operate in discussions with political, socially significant concepts (democratic principles, freedom of speech, criticism, fundamentals of the state, social guarantees, etc.). Taking into account this fact, the work program on terms was included in the program of seminars, which gives the normative basis for the students to shape their own evaluation.

The second pedagogical condition of the development of media competence of university students is actualization of the student's standpoint regarding the implementation of research media projects. The fulfillment of the pedagogical condition was the realization of the stages of the research media projects.

At this stage, we managed to represent the experience of implementing both group and individual media projects, which had been carried out by university students. In the process of working on the media project "Ukraine is Identity at the Border of Europe and Asia", students identified the concept of "identity", conducted a quantitative diagnosis to identify the essence of Ukrainian identity and analyzed the results. By completing a series of tasks, students used the full range of media - the Internet, books and the press. In addition, the research was carried out within the framework of the media project "Ukraine and identity in mass media". The journalists used the most popular Ukrnet search systems, local media, audio-visual media texts related to historical events in Ukraine to find material on the given topic.

A German-language seminar on the presentation of student research from Kyiv, Lviv, Odessa, and Chernivtsi allowed students to identify the significance of the topic itself and the use of all available media in research activities. As a result of the implementation of this media project, students not only enriched their knowledge about the local media landscape, but were able to analyze and compare their own understanding of identity with the understanding of students from other cities in Ukraine.

The media project which consisted in a comparative analysis of media stereotypes in the German comedy "Keinohrhasen" (Ukr. "Красунчик") by T. Schweiger and the Ukrainian melodrama "Female Doctor" (Ukr. "Жіночий лікар") by O. Parkhomenko, was conducted and represented by O. Klimenko, a student of the Faculty of Journalism, at a student's scientific conference in 2018. Based on the media balance, the topic was chosen, the media textbooks were selected and the research tasks were defined. During the work on the media report, the student defined the concept of "media stereotypes"; based on the structure of the plot stereotypes, similar 
FRG and Ukrainian films were selected; a comparative analysis of the elements of the submitted media texts containing the stereotypes of the comedy genre was conducted.

The media project "Music - a Creative or Destructive Force in the World of Teens?", elaborated by A. Rabtsevich, a student of the Faculty of Journalism, revealed and analyzed the musical preferences of adolescents, aged 15-16, pupils of secondary school No. 1 in Chernihiv. The project was implemented with the help of the software application for creation and processing of GrafStat surveys. Such diagnostics allowed to determine the level of value orientations of adolescents and to indicate the forms of their interaction with teachers. The independent choice of the topic, the critical attitude to the media business, the motivation to get knowledge about the forms of influence of media texts on the younger generation and the active position in using the new software application determined the value-semantic level of a student's media competence.

In the realization of the third pedagogical condition - the development and implementation of the model of the development of the students' media competence in the university educational process using the pedagogical experience of media personification in the institutions of higher learning in the FRG - during the classes of the German language and the optional course, the following media education methods were used:

1. Mediabiographic method. Reflecting on media biography, students retrospectively brought back media use in their childhood. The knowledge gained about the various features and media capabilities of the user has been transferred by students on today, which has contributed to a comprehensive understanding of the role of the media in their everyday lives.

2. Method of narrative analysis of media text. In the development of media criticism, drawing the students' attention to the author's idea of media text, to the social basis of the emergence of a media product, to the values conveyed in this product, the algorithm of reflective activity was used in the learning process, the main component of which was the identification in the text of the moral dilemma, expressed by the author by way of presenting a clash of two opposite values. The use of this method encouraged the students to identify the moral dilemma represented by the author, which consequently stimulated the students to resort to their own circumstances, to analyze their life values, their correlation with each other, with the norms of morality and, as a result, to shape their own value priorities.

3. L. Kolberg's method of moral dilemma. Giving their reasons as for L. Kolberg's method of moral dilemma, the students tended to be egocentric as well and demonstrated orientation toward the moral system of society. Therefore, by subtracting from the analysis of data testing of media weights and degrees of moral development of students, students' value assessment of media skills was determined - Does the student listen to socially significant radio broadcasts or is limited to music? Will the student be interested in solving university policy issues and arrange discussions in the social network (for example, "V Kontakte" (Ukr. "B контакті")) or will they send video to the friends there? Thus, finding a valuable comprehension of the students' media space, we had the opportunity not only to promote further active media work, but also to adjust and refine the students' media strengths.

The comparative analysis of the results of the experimental study allowed us to conclude that the pedagogical conditions indicated by us contribute to the development of the university students' media competence, as evidenced by the positive dynamics of the development of their levels of media competence.

Students who have a value-semantic and creative-technological level of development of media competence indicators are characterized by a number of features, in particular: the knowledge of most basic terms, theories, the main facts of the history of media culture 
development, the creativity of media cultures; a clear understanding of the process of mass communication and media influences in the context of the real world; value-semantic attitude to the media space; the desire to independently identify a text problem or a moral dilemma in the media; the use of the Internet (or other media), the desire to search the materials for educational, scientific, research purposes; active position in the use of technical capabilities of media in the structure of a media text.

\section{CONCLUSIONS AND PROSPECTS FOR FURTHER STUDIES}

Thus, despite the fact that the most developed countries of the world community have come ever closer to a qualitatively different stage of development - the information society, a new possibility - electronic - is traced, i.e. information flow and other forms of data organization have come into play. In this regard, media education as a direction in pedagogy committed to teaching to the students the laws of mass communication, the main task of which is to prepare the new generation for life in the modern information environment, for the perception of manifold information, to teach students to understand it, to realize the consequences of such kind of influence on the psyche, to master the ways of communication on the basis of non-verbal forms of communication with the help of technical means and modern information technologies. So, on the one hand, media education tries to adjust the notion of media literacy, i.e. the ability to adequately interact with media information flows in the global information space: to search, analyze, critically evaluate and create media texts distributed through various media and communication channels, in all their diversity of forms. On the other hand, media education involves the notion of media competence, i.e. the result of the personalistic achievements of students in the process of formal and informal learning, which testifies to the readiness of the personality to access the media.

This paper presents an attempt at the scientific approach to teaching media competence through education project. Involving the students of higher educational institutions of Ukraine and the FRG, the experimental study comprised two main stages, i.e. the establishing and the forming ones, yielding some theoretical and practical conclusions and making it possible to reveal both common and distinguishing characteristics across the Ukrainian and the German students. The results of the establishing stage of the experiment revealed an insufficient level of development of media competence of university students, highlighting their main media preferences as value orientations in media space. The forming stage of the experiment resulted in the development and implementation of the model of the development of students' media competence in the university educational process using the pedagogical experience of media personification in the institutions of higher learning in the FRG within the framework of the German language classes and in the optional course. To achieve this aim, such media education methods were used as mediabiographic method, method of narrative analysis of media text, L. Kolberg's method of moral dilemma. Thus, the experimental study allows concluding that the implemented pedagogical methods contribute to the development of the media competence levels of the Ukrainian students, as evidenced by the positive dynamics of the studied characteristics.

We see the prospects of the research in studying how media competence influences the process of creating an environment for the cultural and spiritual growth of the student's personality and defining the role of the media (including new media) in shaping the moral and ethical orientations of youth. 


\section{REFERENCES (TRANSLATED AND TRANSLITERATED)}

1. D. Baake et al. (Eds.). Handbook Media: Media Literacy. Models and projects. Bonn: Federal Agency for Political Imaging, 1999, 176 S. (in German).

2. T. Bakka et al. Media Literacy and Critical Thinking at Social Science Lessons: Teacher's Guide . T. Bakka, O. Burim, O. Voloshenyuk, R. Yevtushenko, T. Meleschenko, O. Mokroguz; Ed. V. Ivanov, O. Voloshenyuk. Kyiv: Free Press Center, AUP, 2016. 243 p. (in Ukrainian).

3. The Conception of Implementation of Media Education in Ukraine. Education. 2010. July 7-14. P. 3-4. (in Ukrainian).

4. The Conception of Implementation of Media Education in Ukraine (New Edition). [online]. Available: https://ms.detector.media/mediaprosvita/mediaosvita/kontseptsiya_vprovadzhennya_mediaosviti_v_ukraini_n ova_redaktsiya. (in Ukrainian).

5. The Conception of the New Ukrainian School. [online]. Available: http://mon.gov.ua/activity/education/zagalnaserednya/ua-sch-2016/konczepcziya.html (in Ukrainian).

6. European Parliament resolution of 16 December 2008 on media literacy in a digital world (2008/2129(INI)). [online]. Available: http://www.europarl.europa.eu/sides/ getDoc.do?pubRef (in English).

7. The European Charter on Media Literacy, 2009-2018. [online]. Available: https://euromedialiteracy.eu/resources.php (in English).

8. H. Gapski Measuring media literacy? Procedures and reflections on the acquisition of key competences. Dusseldorf, kopaed. 2006. 138 S. (in German).

9. Educational program "Media education (media literacy)" for students of higher educational pedagogical establishments, pedagogical and scientific-pedagogical workers, 2013. [online]. Available: http://www.aup.com.ua/uploads/Program_for_student.pdf (in Ukrainian).

10. V. F. Ivanov, O.V. Voloshenyuk Media education and media literacy. Kyiv: Free Press Center. 2012. 352 p. (in Ukrainian).

11. V. F. Ivanov, O.Ya. Shkoba Media Education and Media Literacy: Definition of Terms Information Society. Aug. 16. pp. 41-52. [online]. Available: http://nbuv.gov.ua/UJRN/is_2012_16_10 (in Ukrainian).

12. A. Ishchenko Modern media education: implementation of international experience in Ukraine. Strategic priorities. No. 4 (29). 2013. P. 84-89. (in Ukrainian).

13. L. A. Karpets Modern educational paradigm in the context of media culture. Actual problems of philosophy and sociology. 2015. P. 95-98.

14. Yu. M. Kazakov Pedagogical conditions of the use of media education in the process of professional training future teachers: Avtoref. diss. ... Cand. Ped. Sc: 13.03.04 "Theory and methodology of vocational education". Luhansk, 2007. 21 p. (in Ukrainian)

15. A. V. Kiriakova The Axiology of Education. Fundamental research in pedagogy. M.: House of Education, 2008. 578 p. (in Russian).

16. R. Kubey Media Literacy in the Information Age. New Brunswick; London, 1997. 484 p. (in English).

17. A. Lytvyn Problems of Media Education in the Context of Improving the Quality of Vocational Training. [online]. Available: http://www.nbuv.gov.ua/portal/Soc_Gum/Pippo/2009_4/Lytvyn.htm. (in Ukrainian).

18. G. Marci-Bönke Media Competence of University Students: Requirements for the Quality of Teacher Education and its Opportunities A View from Germany. Bulletin of the Orenburg State University. No. 4. 2009. P. 39-47. (in Russian).

19. M. McLuhan Understanding Media: External Expansions of Man. Moscow: "CANON-press-C". 2003. 464 p. (in Russian).

20. Media education. UNESCO. The Seville Recommendation. Youth Media Education. Paris: UNESCO. 2002. (in English).

21. G.V. Onkovych Media education Experimental program of the basic training course for students of higher educational institutions. Kyiv: Logos, 2010. 41 p. (in Ukrainian).

22. D. Petranova, N. Vrabec Age as a Factor in Evaluation of Media Literacy Levels in Slovakia. International Journal of Media and Information Literacy. Vol. 1. Is. 1. 2016. pp. 18-26. [online]. Available: http://ejournal46.com/journals n/1468935998.pdf. (in English).

23. J. D. Pons Digital technologies and their impact on Higher Education. The new mediations. Ried-Revista Iberoamericana De Educacion A Distancia. Vol. 21. Is. 2. 2018. pp. 83-95. [online]. Available: https://doi.org/10.5944/ried.21.2.20733 (in English).

24. W. J. Potter Media Literacy. Thousand Oaks. London: Sage Publication. 2001. 423 p. (in English). 
25. Practical media literacy: international experience and Ukrainian perspectives: Proceedings of the Fifth International Scientific and Methodological Conference. Kyiv: Free Press Center, Academy of Ukrainian Press. 2017. 393 p. (in Ukrainian)

26. Promt-Server produktive Medienarbeit. [online]. Available: http://www.produktive-medienarbeit.de. (in German).

27. A. Silverblatt Reflections on Information Literacy. International Journal of Media and Information Literacy. Vol. 1. Is. 1. 2016. pp. 54-71. URL: http://ejournal46.com/journals nZ1468936515.pdf. (in English).

28. C. Scheibe, F. Rogov The Teacher's Guide to Media Literacy. Critical Thinking in a Multimedia World. CORWIN, USA. 2012. (in English).

29. I. Snikhovska The Core Competencies of Media and Information Literacy. Recepcja mediów. T. 5. Recepcja mediów przez młodzież w wieku szkolnym i przez osoby doroste . Pod red. B. Bonieckiej, A. Granat. Lublin: Wydawnictwo UMCS. 2018. P. 183-190 (in English).

30. G. Tulodziecki Media education as a task of the German lessons. New Media Edutainment - Media Literacy. German lessons in transition. Munich: Kopad. 1997. S. 39-52. (in German).

31. A. Yelkin School Media Holding - media education space for the formation of media information and environmental culture of schoolchildren. Practical media literacy: international experience and Ukrainian perspectives. 2015. P. 129. (in Ukrainian).

32. I. Zadorozhnaya, V. Kuznetsova Media Education. Encyclopedia of Education . Ed. V.G. Kremen. Kyiv: Yurincom Inter, 2008. 523 p. (in Ukrainian).

Text of the article was accepted by Editorial Team 22.08.2018

\title{
ФОРМУВАННЯ МЕДІАКОМПЕТЕНТНОСТІ СТУДЕНТІВ ГУМАНІТАРНИХ ФАКУЛЬТЕТІВ ПІД ЧАС ВИВЧЕННЯ СПЕЦАЛІЗОВАНИХ ДИСЦИПЛІН
}

\author{
Покровська Ірина Леонідівна \\ доцент, доктор філологічних наук, завідувач кафедри тюркології \\ Київський національний університет імені Тараса Шевченка, м. Київ, Україна \\ ORCID ID 0000-0002-7826-3148 \\ irem2003@ukr.net
}

\begin{abstract}
Анотація. У статті представлено результати дослідно-експериментального дослідження щодо формування медіакомпетентності особистості студента університету в контексті медіаосвіти; надано визначення ключових термінів: медіаосвіта, медіаграмотність, медіакомпетентність. На основі досвіду вищих навчальних закладів України і Федеративної Республіки Німеччини в дослідно-експериментальному дослідженні вдалося простежити як спільні, так і відмінні характеристики в формуванні медіакомпетентності. На констатуючому етапі експерименту були вирішені такі завдання, як: розкриття педагогічної сутності розвитку медіакомпетентності студентів вищої школи в Україні й ФРН; розробка критеріїв, рівнів та етапів розвитку медіакомпетентності студентів; виявлення вихідного рівня розвитку медіакомпетентності українських студентів; визначення медіапереваг українських i німецьких студентів в порівняльному аналізі. На формуючому етапі дослідно-пошукової роботи перевірялася ефективність педагогічних умов розвитку медіакомпетентності студентів університету. Результати констатуючого етапу дослідно-експериментальної роботи виявили недостатній рівень розвитку медіакомпетентності студентів університету, їх основні медійні уподобання як ціннісні орієнтації в медіапросторі. Результатом формуючого етапу є розробка і впровадження в освітній процес університету моделі розвитку медіакомпетентності студентів з використанням педагогічного досвіду медіатизації особистості у вищій школі Німеччини. На заняттях 3 німецької мови та у варіативному спецкурсі використовувалися такі медіаосвітні методи, як медіабіографічний метод, метод наративного аналізу медіатексту, метод моральних дилем Л. Кольберга. Таким чином, проведена дослідно-педагогічна робота дозволяє зробити висновок про те, що використані педагогічні методи сприяють розвитку рівнів медіакомпетентності
\end{abstract}


студентів, про що свідчить позитивна динаміка досліджених показників в українських студентів.

Ключові слова: медіаосвіта; медіаграмотність; медіакомпетентність; дослідноекспериментальне дослідження; констатуючий і формуючий етапи.

\title{
ФОРМИРОВАВАНИЕ МЕДИАКОМПЕТЕНТНОСТИ СТУДЕНТОВ ГУМАНИТАРНЫХ ФАКУЛЬТЕТОВ ВО ВРЕМЯ ОБУЧЕНИЯ СПЕЦИАЛИЗИРОВАННЫХ ДИСЦИПЛИН
}

\author{
Покровская Ирина Леонидовна \\ доцент, доктор филологических наук, заведующий кафедрой тюркологии \\ Киевский национальный университет имени Тараса Шевченко, Киев, Украина \\ ORCID ID 0000-0002-7826-3148 \\ irem2003@ukr.net
}

\begin{abstract}
Аннотация. В статье представлены результаты опытно-экспериментального исследования по формированию медиакомпетентности личности студента университета в контексте медиаобразования; даны определения ключевым терминам: медиаобразование, медиаграмотность, медиакомпетентность. На основе опыта высших учебных заведений Украины и Федеративной Республики Германия в опытно-экспериментальном исследовании удалось проследить как общие, так и отличительные характеристики в формировании медиакомпетентности студентов. На констатирующем этапе эксперимента были определены такие задачи, как: раскрытие педагогической сущности развития медиакомпетентности студентов высшей школы в Украине и ФРГ; разработка критериев, уровней и этапов развития медиакомпетентности студентов; выявление исходного уровня развития медиакомпетентности украинских студентов; определение медиапреимуществ украинских и немецких студентов в рамках сравнительного анализа. На формирующем этапе опытно-поисковой работы проверялась эффективность педагогических условий развития медиакомпетентности студентов университета. Результаты констатирующего этапа опытно-экспериментальной работы показали недостаточный уровень развития медиакомпетентности студентов университета, их основные медийные предпочтения как ценностные ориентации в медиапространстве. Результатом формирующего этапа является разработка и внедрение в образовательный процесс университета модели развития медиакомпетентности студентов с использованием педагогического опыта медиатизации личности в высшей школе Германии. На занятиях по немецкому языку и в вариативном спецкурсе использовались такие медиаобразовательные методы, как медиабиографический метод, метод нарративного анализа медиатекста, метод моральных дилемм Л. Кольберга. Таким образом, проведенная опытно-педагогическая работа позволяет сделать вывод о том, что использованные педагогические методы способствуют развитию уровней медиакомпетентности студентов, о чем свидетельствует положительная динамика исследованных показателей у украинских студентов.
\end{abstract}

Ключевые слова: медиаобразование; медиаграмотность; медиакомпетентность; опытноэкспериментальное исследование; констатирующий и формирующий этапы.

\section{(cc) BY-NC-SA}

This work is licensed under Creative Commons Attribution-NonCommercial-ShareAlike 4.0 International License. 